\title{
Reliability Prediction for MAN-MACHine PRODUCTION LINES
}

\author{
KARAUlOVA, T. \& PRIBYTKOVA, M.
}

Abstract: Reliability prediction plays a very important role in system design and evaluation. In order to accurately predict the system reliability, one should consider the system configuration and the failure distribution of its components. Nowadays the requirements on reliability of the complex mechanisms and machines are constantly rising. Suppliers, who are able to "manage" reliability of developed and manufactured mechanisms and machines, have significant competitive advantages. The process reliability analysis helps define a strategic course of action for making improvement.

Present paper introduces the reliability analysis of prototype production line process. The modelling method was used for process analysis considering complex dependences among various parts of the system.

Key words: production line reliability, human factor, process FMEA, MTBF
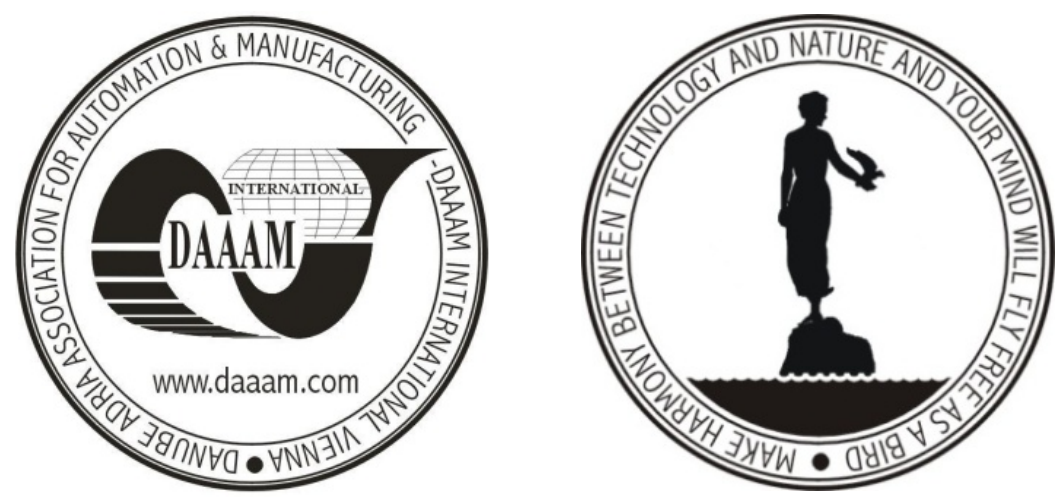

Authors data: Dr. Karaulova, T[atyana]*; M. Sc. Eng. Pribytkova, M[arina] **, *Tallinn University of Technology, Ehitajate tee 5, 19086, Tallinn, EE, **AS Norma, Laki 14, Tallinn,EE, tatjana.karaulova@ttu.ee, marina.pribotkova@autoliv.com

This Publication has to be referred as: Karaulova, T[atyana] \& Pribytkova, M[arina] (2009). Reliability Prediction for Man-Machine Production Lines, Chapter 49 in DAAAM International Scientific Book 2009, pp. 487-500, B. Katalinic (Ed.), Published by DAAAM International, ISBN 978-3-901509-69-8, ISSN 1726-9687, Vienna, Austria

DOI: $10.2507 /$ daaam.scibook.2009.49 